\title{
半導体レーザー光がサラダナ生育に及ぼす影響
}

\author{
山崎 文・土屋広司・宮島博文・本間孝宜・菅 博文 \\ 浜松ホトニクス株式会社 434-8601 静岡県浜北市平口 5000 番地
}

\section{Effect of Laser-diode Light on Growth of Lactuca sativa $\mathrm{L}$.}

\author{
Aya Yamazaki, Hiroshi Tsuchiya, Hirofumi Miyajima, \\ Takayoshi HonMA and Hirofumi KAN \\ Hamamatsu Photonics K. K., 5000 Hirakuchi, Hamakita, Shizuoka 434-8601, Japan
}

\begin{abstract}
Development of an effective, high-power, low-cost, artificial light source for use in plantgrowing facilities would be very beneficial for plant production.

Recently, the laser-diode lamp has been proposed as a new type of light source for plant production. The advantages of the laser-diode lamp over conventional light sources are its high electrical-to-optical power conversion efficiency, low thermal radiation, easy set-up for high power and pulse irradiation, small weight and small volume for mounting, and selectivity for proper wavelength.

Because laser light itself differs from the light sources presently used in plant growing, we confirmed the possibility of growing plants under the laser-diode light by growing lettuce (Lactuca sativa L.) plants.

Lettuce seedlings with 5-6 leaves were grown under a laser-diode lamp panel with 30 pieces of high-power and high-efficiency AlGaInP laser-diodes. The power of each laser-diode lamp was $500 \mathrm{~mW}$, and the wavelength was $680 \mathrm{~nm}$, which was efficient for photosynthesis.

The lettuce plants were able to grow under the laser-diode light. However, the weight of the lettuce plants grown under the laser-diode lamps was light, and their leaves were long and thin compared to those of lettuce plants grown under high-pressure sodium lamps.
\end{abstract}

Keywords : light source, laser-diode lamp, plant production

\section{緒 言}

半導体レーザーは, 電力一光変換効率を既存の光源中 で最も高くできる可能性を持ち, 熱放射が少なく, 高出 力化とパルス照射が容易で, 小型軽量であり, 最適な波 長を選択発光できるなど, 従来の植物栽培用光源には無 い特徴を持つために, 植物栽培用の新たな光源として, 注目され始めた ${ }^{1)}$. 半導体レーザーの植物栽培への利用

1999 年 9 月 27 日受付

2000 年 1 月 11 日受理
の可能性は早い時期から論じられていたが2), 従来, 半 導体レーザーは光通信や CD プレイヤー用などとして開 発されていたために, 植物の光合成有効放射域から外れ た $700 \mathrm{~nm}$ 以上で発振し, 植物栽培に適さなかった.

最近の半導体レーザー開発技術の発展により, 光合成 有効放射域内の $700 \mathrm{~nm}$ 以下の短波長で発振する半導体 レーザーが開発された. ガリウム砒素系を材料とした赤 色半導体レーザーは $600 \mathrm{~nm}$ 以上で発振し, 窒化ガリウ ム系を材料とした青色半導体レーザーは $400 \mathrm{~nm}$ 付近で 発振する.ガリウム砒素系の半導体レーザーは $700 \mathrm{~nm}$ に近いほど植物栽培に重要とされる光パワーと電力-光 
変換効率を向上する.

本実験で用いた半導体レーザーは，植物の光合成作用 スペクトルのピーク付近に相当する $680 \mathrm{~nm}$ で発振し,

1 素子あたり $500 \mathrm{~mW}$ 以上の出力を持つ2). この半導体 レーザーを複数用いることで, 植物栽培に十分な光強度 が容易に確保でき，従来植物工場などで問題とされてい た光源に関わる電力消費量を大幅に減らせる可能性が出 てきた。

そこで, 干渉性が高く, 鋭い単色性を有する半導体レ ーザー光という特殊な光の下で，植物がどのように生長 するかを，栄養生長段階で収穫されるサラダナを供試し て，実験的に検討した。

\section{材料および方法}

\section{1. 植物材料}

植物材料として, サラダナ (Lactuca sativa L. 品種： 岡山サラダナ)の苗を供試した.

1 粒ずつ播種した水耕用ウレタンキューブ(縦 $25 \times$ 横 $25 \times$ 高さ $30 \mathrm{~mm}$, (株) M式水耕研究所製) 80 個を育苗室 内に 15 日間置いて, 第 6 葉が展開し始めた植物体を苗 とした. 育苗室内は, 育苗面における光合成有効光量子 束(Photosynthetic photon flux, 以下PPF) $150 \mu \mathrm{mol}$ $\mathrm{m}^{-2} \mathrm{~s}^{-1}$, 明期 $12 \mathrm{~h} \mathrm{~d}^{-1}$, 明暗周期 $24 \mathrm{~h}$, 気温 $20^{\circ} \mathrm{C}$, 相対 湿度 65〜 75\% に管理した. 光源には昼白色蛍光灯(FL $20 \mathrm{SSN} / 18$, 松下電器産業(株)製)を用いた. 育苗中, 大塚ハウス肥料 1 号 $1000 \mathrm{mg} l^{-1}, 2$ 号 $533 \mathrm{mg} l^{-1}$ および 3 号 $133 \mathrm{mg} l^{-1}$ (いずれも大塚化学(株)製)を混合して, $\mathrm{pH} 6.0 \pm 0.5, \mathrm{EC}$ (電気伝導度) $20 \mathrm{mS} \mathrm{m}^{-1}$ に調節した培 養液を適宜与えた。

\section{2. 実験装置}

浜松ホトニクス(株)で試作した, 波長 $680 \mathrm{~nm}$, 駆動 電流 $1250 \mathrm{~mW}$ における光出力 $500 \mathrm{~mW}$ の赤色半導体レ ーザー素子(以下，素子と呼ぶ) 30 個を植物栽培実験用 光源パネル (以下, 光源パネルと呼ぶ)上のアルミ製放熱 器(横 $40 \times$ 縦 $40 \times$ 高さ $10 \mathrm{~mm}$ ) にそれぞれ取り付けた (Fig. 1).

素子の発光パターンは細長い(Fig. 2)ので, 栽培面に おける PPF 分布が均一になるように, 1 列 6 素子, 5 列として，各列を交互に $13 \mathrm{~mm}$ ずらし(Fig. 1)，また各 素子は列に対して直角に, 細長く発光するように配置し た。

栽培面上の PPF は素子の駆動電流値を変えることで 調節した。気温，相対湿度および明暗期が制御可能な植 物生育室内の栽培面から約 $60 \mathrm{~cm}$ 上に光源パネルを設
$300 \mathrm{~m} \mathrm{~m}$

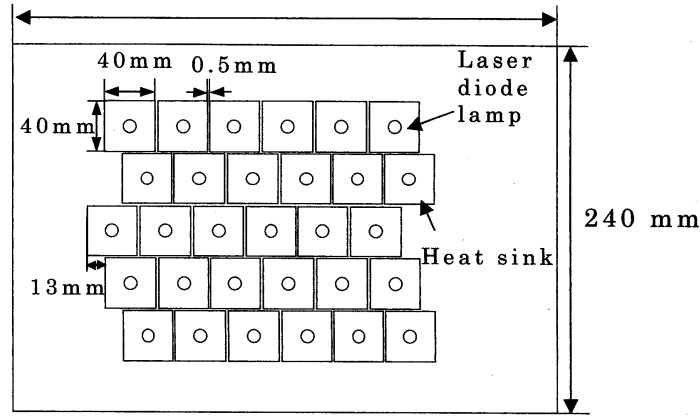

図 1 半導体レーザー光源パネルの模式図

Fig. 1 Schematic diagram of the laser-diode lamp panel

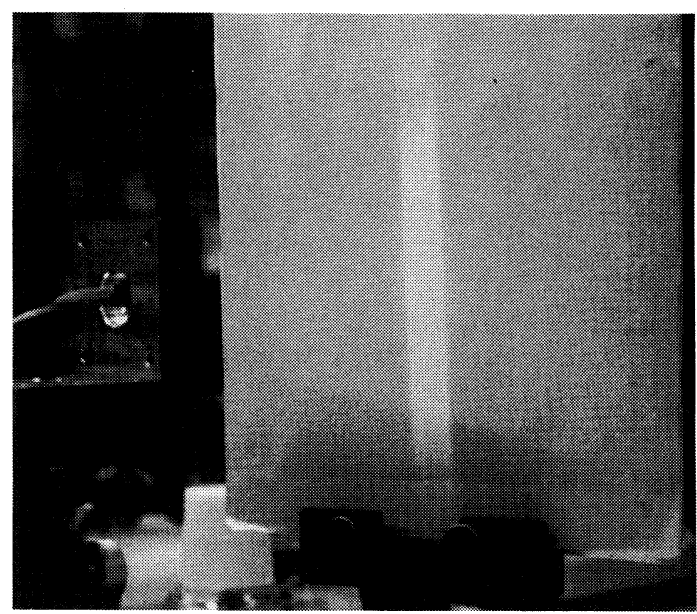

図 2 半導体レーザー素子照射面に垂直な面における 光強度 2 次元パターン

Fig. 2 Two-dimensional intensity distribution of the laser light on the surface parallel to the emitting face of the laser-diode lamp

置した。また，同仕様の植物生育室に高圧ナトリウムラ ンプ(定格ランプ電力 $85 \mathrm{~W}$, NHR 85 D. L, (株) 日立製作 所製) 9 本を光源として設置し，対照区とした.ランプ の放熱によるチャンバー内の温度上昇を避けるために, 熱吸収フィルターとして, ランプ下 $80 \mathrm{~mm}$ の位置に, 水道水を入れたアクリル製の水槽(縦 $700 \times$ 横 $1000 \times$ 高 さ $50 \mathrm{~mm}$, 底部のアクリルの厚さ $10 \mathrm{~mm}$, 水深 $25 \mathrm{~mm}$ ) を設置した。

\section{3. 実験方法}

植物材料を，発泡スチロール製板(縦 $300 \times$ 横 $300 \times$ 高 さ $30 \mathrm{~mm}$, 株間 $55 \times 70 \mathrm{~mm}$, (株) $\mathrm{M}$ 式水耕研究所製)に 定植し, 光源パネルまたは高圧ナトリウムランプが設置 
してある植物生育室に移動し，水耕した，植物生育室は， PPF $300 \mu \mathrm{mol} \mathrm{m}^{-2} \mathrm{~s}^{-1}$, 明期 $12 \mathrm{~h} \mathrm{~d}^{-1}$, 明暗周期 $24 \mathrm{~h}$, 気 温 $20^{\circ} \mathrm{C}$, 相対湿度 $65 \sim 75 \%$ に設定し, 育苗時と同じ培 養液を使用した。

定植個体数は 6 とし, 定植後 3 日目に 2 個体, 7 日目 に 2 個体, 14 日目に 1 個体をサンプリングし, 地上部 乾物重, 葉数, 最長葉の葉身長および葉幅を測定した. 最終的に残った 1 個体は 21 日目に, 生体重 (地上部, 地 下部) および乾物重 (地上部, 地下部), 葉数, 葉面積, 最長葉の葉身長と葉幅を測定した。実験は 2 反復した。

\section{結 果}

\section{1. 半導体レーザー光が生長量に及ぼす影響}

Table 1 に定植後 21 日目のサラダナの生体重, 乾物
重および葉面積を示す，半導体レーザー区の地上部生体 重は $64 \mathrm{~g}$ であるのに対し, 高圧ナトリウムランプ区で $113 \mathrm{~g}$ となり, 前者は後者の $57 \%$ であった。地下部生体 重は，半導体レーザー区で $8 \mathrm{~g}$, 高圧ナトリウムランプ 区で $15 \mathrm{~g}$ となり, 前者は後者の $53 \%$ となった。乾物重 および葉面積に関しても，半導体レーザー区では高圧ナ トリウムランプ区と比較して有意に少なかった.

Fig. 3 に定植後の地上部乾物重の経日変化を示す．定 植後 3 日目では, 両区で大きな差は見られなかったが, 定植後 7 日目以降, 半導体レーザー区のサラダナの乾物 重は高圧ナトリウム区と比較し, 少ない結果となった.

\section{2. 半導体レーザー光が展開葉数に及ぼす影響}

Fig. 4 に, 定植後の展開葉数の経日変化を示した. 定 植直後から 21 日目まで, 半導体レーザー区と高圧ナト リウム区の展開葉数に有意差は見られなかった。

表 1 半導体レーザーおよび高圧ナトリウムランプ下で 21 日間栽培したサラダナの生体重, 乾物重, 葉面積

Table 1 Fresh and dry weights and leaf area per plant of lettuce plants grown under laserdiode lamp and high-pressure sodium lamp with heat-absorbing filter (21 days after planting)

\begin{tabular}{|c|c|c|c|c|c|}
\hline \multirow{2}{*}{ Light source } & \multicolumn{2}{|c|}{ Fresh weight $(\mathrm{g})$} & \multicolumn{2}{|c|}{ Dry weight $(g)$} & \multirow{2}{*}{$\begin{array}{c}\text { Leaf area } \\
\left(\mathrm{cm}^{2}\right)\end{array}$} \\
\hline & Shoot & Root & Shoot & Root & \\
\hline Laser diode lamp & $64 \pm 5$ & $8 \pm 1$ & $3.7 \pm 0.4$ & $0.4 \pm 0.0$ & $1229 \pm 124$ \\
\hline High pressure sodium lamp & $113 \pm 17$ & $15 \pm 2$ & $6.8 \pm 1.0$ & $0.7 \pm 0.1$ & $2198 \pm 116$ \\
\hline
\end{tabular}

Each value represents the mean of 2 samples of 2 replications.

${ }^{z}$ Mean \pm S. D.

迥

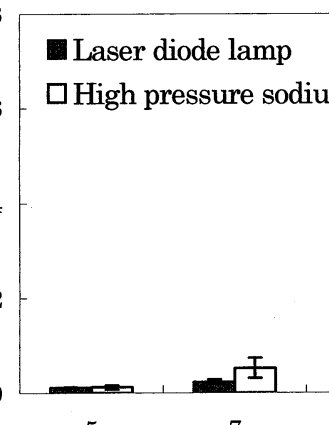

(4)

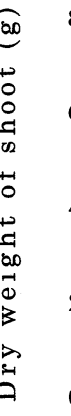

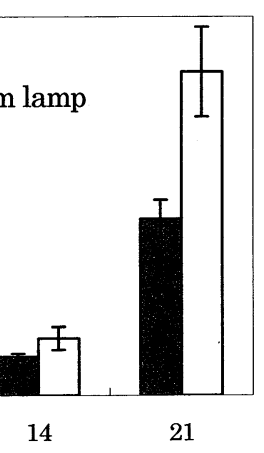

(2)

(2)

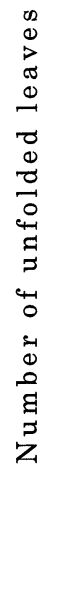

Days after planting

図 3 地上部乾物重

Fig. 3 Dry weight of shoot per plant

$\left({ }^{*}\right)$ shows the number of total samples of 2 replications.

Vertical bars represent $\pm S$. D. of the means

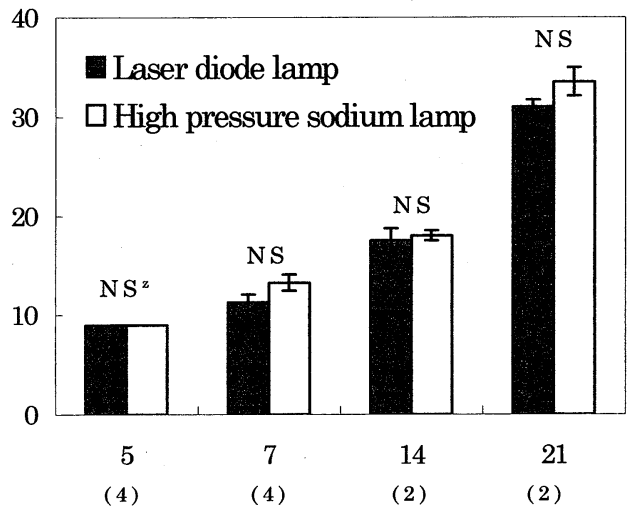

Days after planting

図 4 展開葉数の経日変化

Fig. 4 Changes with time in the number of unfolded leaves per plant

Vertical bars represent $\pm S$. D. of the means. $\left({ }^{*}\right)$ shows the number of total samples of 2 replications.

${ }^{z} \mathrm{NS}$, non-significant differences respectively, by $\mathrm{T}$-test. 


\section{3. 半導体レーザー光がサラダナの形態に及ぼす影響}

Fig. 5 に，定植後 21 日目のサラダナを真上から撮影 した写真を示す。半導体レーザー光下で生育した個体の 葉は, 細長く, 葉縁が外側に巻く傾向が見られた。また, 葉の付け根がねじれ, 葉の表面が横向きまたは下向きに なるものがあった，他方，高圧ナトリウムランプ下で生 育した個体の葉は，およそ円形であり，葉縁は巻かず， 自然光下で生育したサラダナと同様な形態を示した。

Fig. 6 に, 個体当たり最長葉の W/L 比(葉幅/葉身長 比)の経日変化を示す. 定植後 5 日目の W/L 比は, 半 導体レーザー区で 0.42 , 高圧ナトリウムランプ区で 0.57 となり, 半導体レーザー区の葉は高圧ナトリウム ランプ区よりも細長くなる傾向が見られた，生育が進む

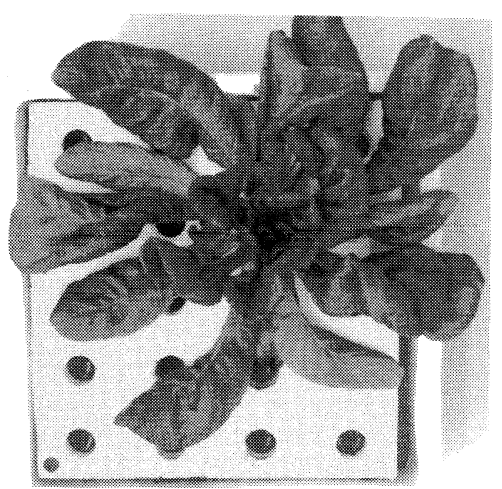

(a ) Laser diode lamp

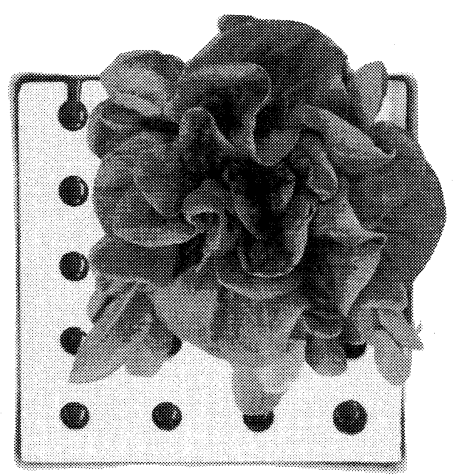

(b) High pressure sodium lamp with heat-absorbing filter

図 5 半導体レーザー(a)および熱吸収フィルター付 き高圧ナトリウムランプ(b)下で栽培したサラ ダナ (定植後 21 日目)

Fig. 5 Lettuce plants grown under laser-diode lamp(a) and high-pressure sodium lamp with heat-absorbing filter (b)

(21 days after planting)

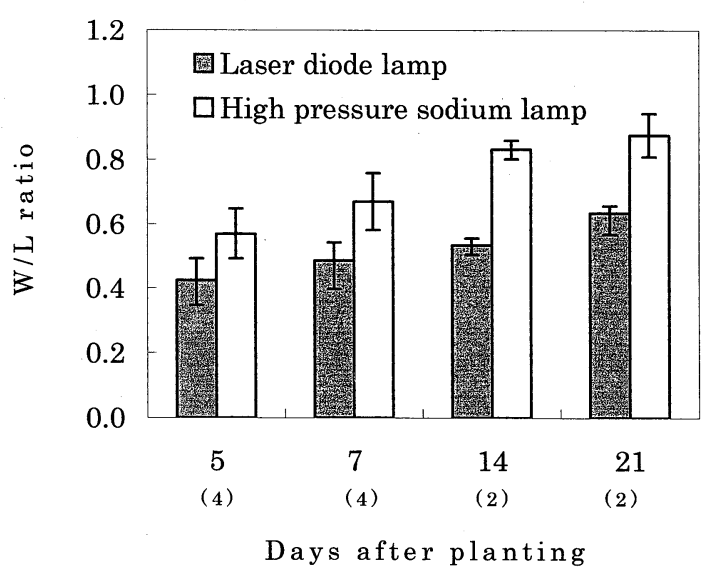

図 6 サラダナの最長葉の横/綐比

Fig. 6 Leaf width/leaf length (W/L) ratio of the longest leaf per plant

$\left.{ }^{*}\right)$ shows the number of total samples of 2 replications.

Vertical bars represent \pm S. D. of the means

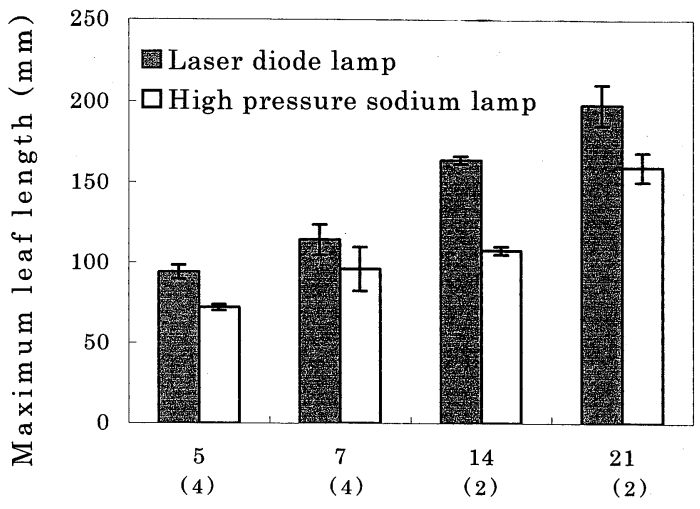

Days after planting

図 7 サラダナの最長葉の葉身長

Fig. 7 Maximum leaf length per plant

${ }^{*}$ ) shows the number of total samples of 2 replications.

Vertical bars represent $\pm S$. D. of the means

につれて, 両区とも $\mathrm{W} / \mathrm{L}$ 比の值が上昇し, 定植後 21 日目の W/L 比は, 半導体レーザー区で 0.63 , 高圧ナト リウムランプ区で 0.88 となった.

Fig. 7 に, 個体あたり最長葉の葉身長の経日変化を示 す. 最長葉の葉身長は, 生育期間を通じて, 半導体レー ザー区の方が高圧ナトリウムランプ区よりも有意に長か つた。 


\section{考察}

半導体レーザー光下でサラダナを栽培したところ, 試 験期間内に, 生体重, 乾物重, 葉面積, 本葉数の増加が 見られたことから，干渉性が高く，鋭い単色性を有する 半導体レーザー単色光 (波長 $680 \mathrm{~nm}$, 以下レーザー光) 下でも, サラダナが生育することが確認された。

生長量の指標とした生体重, 乾物重および葉面積の值 が, レーザー光下と高圧ナトリウムランプ下で大きな差 が生じたのは, レーザー光と高圧ナトリウムランプの光 合成能力への影響の違いと推察される.レーザー光下で の地上部乾物生産量は, 定植後 7 日目から, 高圧ナトリ ウムランプのものよりも少なくなったことから, 両ラン プは同じ PPF でも, 純光合成速度が異なった事が推察 されるが，現時点では断定はできない．この光合成速度 の差に関して確認するために，生長量の違いを光合成の 観点から更に考究する必要がある.

また，葉の展開速度で，光源による有意な差が見られ なかったのは, 両ランプの葉の分化および展葉に対する 効果が同等であったことが考えられる.

レーザー光で栽培した個体で見られた葉が細長く徒長 し, 葉縁が外側に巻きこみ, 葉の表面の向きが不均一と なるなどの形態異常は, 単一波長下で栽培されたサラダ ナに特有の形態と推測される。筆者らの知る限り, レー ザー光のみでサラダナが生育することを示した論文は他 に見当たらない. そのため, この特有な形態が赤色レー ザー光(600-700 nm)一般の効果なのか, $680 \mathrm{~nm}$ に特有 な効果なのかは定かでない. そこでこの結果の一般性, 原因などについては, 今後の研究が必要である.

森・高辻 ${ }^{3)}$ は, 波長 $650 \mathrm{~nm}$ の赤色レーザー光と波長 $450 \mathrm{~nm}$ (半幅值 $70 \mathrm{~nm}$ ) の青色発光ダイオード光 (以下, LED 光)の混合光下でサラダナを生育させて, 葉がやや 細長く，徒長傾向であったと報告した，彼らの実験では， 栽培トレイ上の PPF が $50 \mu \mathrm{mol} \mathrm{m} \mathrm{m}^{-2} \mathrm{~s}^{-1}$ であり, 本実 験におけるPPF $300 \mu \mathrm{mol} \mathrm{m}{ }^{-2} \mathrm{~s}^{-1}$ の 1/6 と低い. また, 赤色レーザー光に対して青色 LED 光は PPF で $1 / 10$ で ある. 青色 LED 光を加えたのは, サラダナの葉が徒長 するのを抑制するためであったと考えられる。この実験 において, 葉が徒長傾向となったのは, PPF が低かっ たこと, レーザー光であったことのいずれかまたは両方 が関与しているのかは明らかでない. 従って, 単色性が 強いなどの特徴を有するレーザー光が植物の光合成およ び光形態形成のどの程度影響を及ぼすのかを明らかにす る必要がある。
植物の光形態形成は，波長組成に大きく影響されるこ とが知られている. 特に赤色光, 遠赤色光および青色光 に関する報告が数多くある. Morgan and Smith ${ }^{4)}$, 村

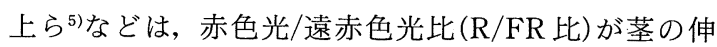
長生長を左右するとしている，また，福田ら ${ }^{6}$ は，赤色 光と青色光の割合により, レタスおよびホウレンソウの 葉の面積や形態が変化することを示唆している.

レーザー光と比較して放射スペクトルの幅が広い単色 光源である LED を用いた研究では, R. J. Bula ら ${ }^{7)}$ は, 赤色 LED と青色蛍光灯を組み合わせてサラダナを, C. S. Brown $~^{8}$ は赤色 LED と青色蛍光灯でトウガラシを, 岡本ら ${ }^{9)}$ と高辻ら ${ }^{10)}$ は, 赤色 LED と青色 LED でサラダ ナを, 渡辺ら ${ }^{11}$ は, 赤色 LED と遠赤色 LED および赤 色 LED と青色 LED の組み合わせでサラダナ，八ツカ ダイコン, リーフレタスを正常に育てることができたと 報告している，また，渡辺ら ${ }^{11}$ は, 赤色 LEDのみでシ ユンギク, エンダイブ, コマツナ, チンゲンサイ, モロ ヘイヤが正常な形態で生育したと報告している.

上記と同様な傾向がレーザー光でも見られるのか, ま た, $680 \mathrm{~nm}$ のレーザー光に, 青色光や遠赤色光など他 の波長の光を組み合わせることで，正常なサラダナが生 育するかどうか興味ある研究課題である.

今後は, 赤色レーザー光が光合成に及ぼす影響を調べ ると同時に, 青色光等, 他の波長域の光が植物の生長お よび形態形成, 品質へ及ぼす影響を調べ, 栽培電力低減 効果が期待される半導体レーザーの植物栽培への応用の 可能性を引き続き検討する.

\section{引用文献}

1）高辻正基, 山中正宣：レーザー植物工場の可能性, 応用物理, 63(11)：1127-1130(1994)

2) 菅 博文, 神崎武司, 宮島博文, 伊藤之弘, 畫馬 輝夫：高出力 $\mathrm{LD}$ アレイ, レーザー研究, 24(3): 334-342(1996)

3）森 康裕, 高辻正基：LED と LD 光がサラダナ 生育に及ぼす影響, 植物工場学会誌, 11(1)：4649 (1999)

4) Morgan, D. C. and Smith, H. : Linear relationship between phytochrome photoquilibrium and growth in plants under simulated natural radiation, Nature, 262 : 210-212 (1976)

5）村上克介，洞口公俊，森田政明，相賀一郎：遠赤 色光付加照射によるヒマワリ幼植物の伸長成長制 御, 生物環境調節, $29(2): 73-79(1991)$

6）福田直也，池田英男，奈良 誠：光質が人工環境 下で栽培したレタスならびにホウレンソウの生育 に及ぼす影響，農業施設，24(2)：77-84 (1993) 
7) Bula, R. J., Morrow, R. C., Tibbitts, T. W., Barta, D. J., Ignatius, R. W. and Martin, T. S. : Light-emitting diodes as a radiation source for plants, HortScience, 26 (2) : 203-205 (1991)

8) Brown, C. S., Schuerger, A. C. and Sager, J. C. : Growth and photomorphogenesis of pepper plants under red light-emitting diodes with supplemental blue or far-red lighting, J. Amer. Soc. Hort. Sci., $120(5)$ : 808-813(1995)
9）岡本研正, 柳 智博: 青/赤超高輝度発光ダイオ ードを用いた植物育成用光源の開発, 農業および 園芸，70(1)：32-34(1995)

10）高辻正基, 辻 . 貴之, 関 善範, 星 岳彦: 可視 発光ダイオードによる植物栽培実験, 植物工場学 会誌，7(3)：163-165(1995)

11）渡辺博之：LED 光源の植物工場 への適用, SHITA Report, $11: 31-41$ (1996) 